\title{
Resilience, replacement and acculturation in the Mesolithic/Neolithic transition: The case of Muge, central Portugal
}

\author{
Nuno Bicho a,", João Cascalheiraa ${ }^{\mathrm{a}}$, Célia Gonçalves ${ }^{\mathrm{a}}$, Cláudia Umbelino ${ }^{\mathrm{a}, \mathrm{b}}$, \\ Daniel García Rivero ${ }^{a}$, , Lino Andréa \\ a ICArEHB, FCHS, Universidade do Algarve, Campus de Gambelas, 8005-139, Faro, Portugal \\ ${ }^{\mathrm{b}}$ CIAS, Departamento de Ciências da Vida, Universidade de Coimbra, Calçada Martim de Freitas, \\ 3000-456, Coimbra, Portugal \\ ${ }^{c}$ Departamento de Prehistoria y Arqueología, Universidad de Sevilla, Doña María de Padilla, s/n, \\ 41004, Seville, Spain
}

* Corresponding author: nbicho@ualg.pt (N. Bicho).

\begin{abstract}
Evidence for the first Neolithic population in central Portugal dates to as early as c. 7600 cal BP. These first farmers were exogenous groups arriving to the Atlantic coast from the Mediterranean Sea. For a few centuries there seems to have occurred an overlap in the region between the Mesolithic Muge hunter-gatherers and the regional early Neolithic populations. While the trajectory of these first farmers seems to be well established, the fate of the Mesolithic populations is unknown and in generally assumed as resulting in extinction. The recent results from research in the Muge Mesolithic shellmounds (Tagus valley) with the new recovery of various loci with Neolithic occupations including human burials, human DNA, and Strontium analyses seem to indicate evidence of cultural and genetic integration between the Mesolithic and Neolithic populations.

This paper will focus on the Mesolithic-Neolithic transition in Portuguese Estremadura and examines the hypothesis that human resilience promoted the cultural and biological integration of the Mesolithic groups into the new exogenous Neolithic communities in central Portugal.
\end{abstract}

\section{Introduction}

The Mesolithic-Neolithic transition was a period of major economic, technological and social transformation, marking the disappearance of the last hunter-gatherers of Western Europe and the replacement by a new human economy based on a food producing system. The case of Portugal, and more specifically of the Tagus Valley where the well-known Muge shellmiddens are located (Fig. 1), seems to be a perfect set-up to evaluate the importance of resilience (Holling, 1973; Redman, 2005; Redman and Kinzig, 2003) in processes of prehistoric cultural extinction. This is due to the fact that the Tagus Valley, some 7500 years ago, witnessed an important drastic dynamic process with the replacement of hunter-gatherers by farmers within a radical social, economic and technological change in human adaptations to the regional ecological factors.

A new economic and social adaptation developed in the Muge region during the Mesolithic (Bicho et al., 2010) after the long term Pleistocene human adaptations that persisted in central Portugal during the early Holocene (Araújo, 2015; Bicho, 1994). Estuarine resources played a very important role in the new Muge Mesolithic population (Bicho et al., 2010), likely responding to the new ecological conditions resulting from the 8.2 K cold event (Barber et al., 1999; von Grafenstein et al., 1998) seen in the Portuguese 
coast (Soares, 2005). Cores collected in the Muge floodplain show that around 8,2 Ka cal BP the valley was transformed into a estuarine setting with salt water and tide influence (van der Schriek et al., 2008). This new set of conditions was marked by two fundamental settlement factors for the local Mesolithic people: permitted a rapid and easy access by boat to the Atlantic coast; and the areas immediately adjacent to the sites were extremely rich in estuarine resources such as fish and shellfish. According to van der Schriek et al. (2008), this ecological setting suffered major alterations only after $5800 \mathrm{cal} \mathrm{BP}$, when tidal influence and estuarine conditions disappeared in the valley. In terms of vegetation cover, open pine forests covered the region starting at $8150 \mathrm{cal} \mathrm{BP}$, with a change to more arid conditions and more open oak landscape over a thousand years later (van der Schriek et al., 2008), already during Neolithic times. This change, although partially natural, may have also had a major impact with the farming due to slash and burn to prepare the fields. The highly productive environment $8.2 \mathrm{ka}$ ago made possible the consolidation of the new social system of complex hunter-gatherers seen in the regional archaeological record (Bicho, 2009; Bicho et al., 2011), with a duration of close to a 1000 years that in the final few hundred years coincided with the emergence of Neolithic farming communities in the Portuguese Estremadura (Bicho et al., 2013). Although there were likely small local and regional environmental changes during the Mesolithic in Muge, data indicates that major ecological changes took place only after the disappearance of the regional Mesolithic communities.

In central Portugal, the evidence for Neolithic communities present in the region started as early as c. 7600 cal BP in sites such as Caldeirão and Almonda caves, or the rockshelter of Pena d'Água (Carvalho, 2007). These communities were exogenous groups coming from the Mediterranean, bordering the southern Portuguese Atlantic coast (Zilhão, 1993). Thus, there seems to be an overlap in the region (i.e., Portuguese Estremadura and the Tagus valley) of a few hundred years between the Muge Mesolithic and the early Neolithic populations. While the cultural evolution of the first farmers is well established, the fate of the Mesolithic populations is still unknown (e.g., Jackes et al., 1997; Lubell and Jackes, 1988; Lubell et al., 1994), Umbelino, 2006).

Recent results from Muge, including human DNA, mobility based on Strontium analyses and the presence of the Neolithic loci and human burials in Cabeço da Amoreira, seem to indicate that social resilience was the major factor in the human adaptations that occurred in the region with a cultural and biological combination between the local Mesolithic and the exogenous Neolithic populations.

This paper discusses the available data and, based on Resilience Theory, presents a hypothesis on the adaptive process of the Mesolithic population of the Tagus valley. 


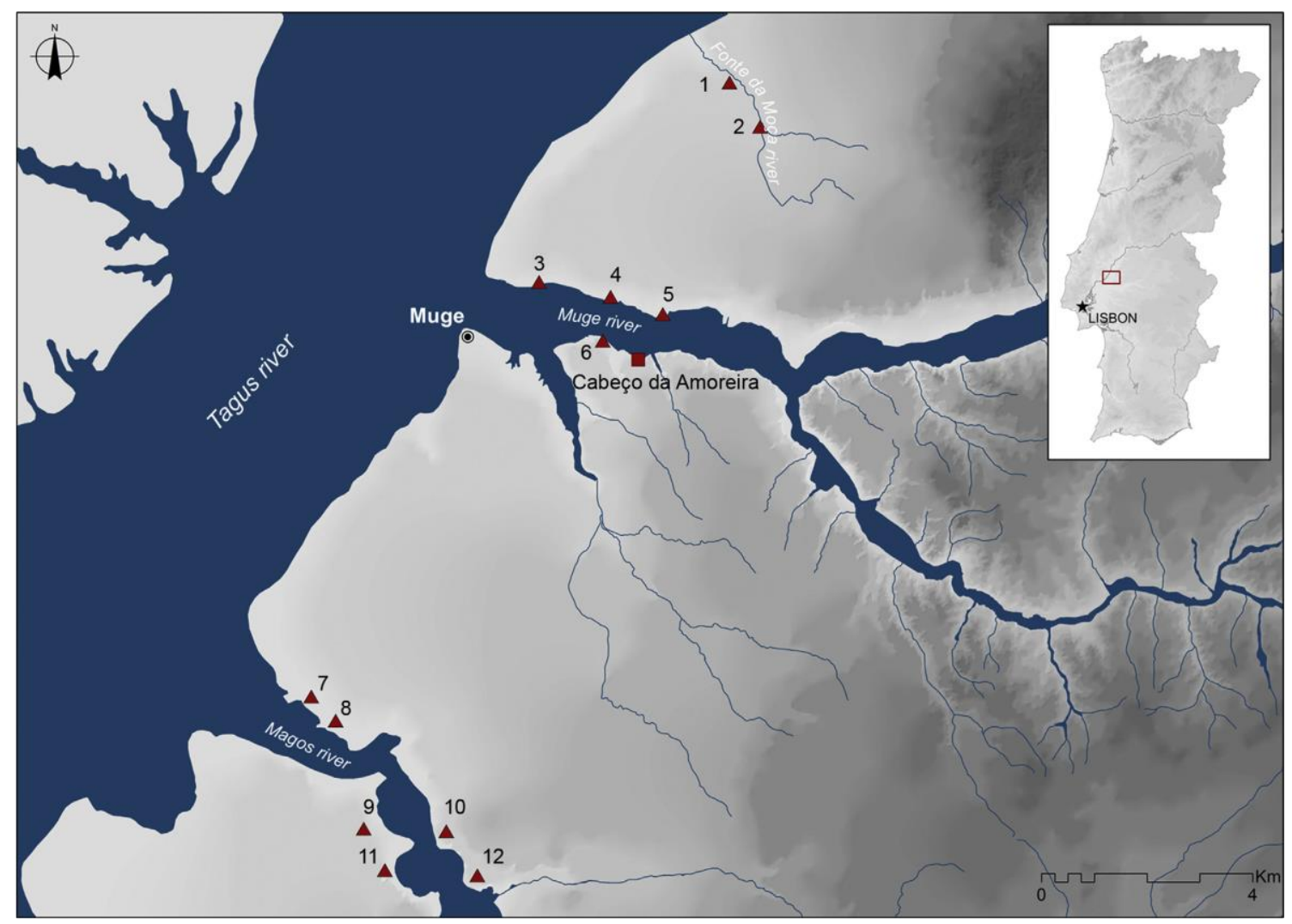

Fig. 1. Map with the Mesolithic shellmiddens in the Muge region. 1. Fonte da Moça I; 2. Fonte da Moça II; 3. Fonte do Padre Pedro; 4. Flor da Beira; 5. Cabeço da Arruda; 6. Moita do Sebastião; 7. Cova da Onça; 8. Monte dos Ossos; 9. Cabeço dos Morros; 10. Magos de Cima; 11. Magos de Baixo; 12. Cabeço da Barragem.

\section{Resilience theory and Archaeology}

The application of Resilience Theory (Folke, 2006) is frequently part of the Panarchy theoretical framework (Gunderson and Holling, 2002; Holling, 2001; Holling et al., 2002). The latter uses a heuristic tool, the Adaptive cycle, graphically represented by a $\infty$, and includes three main variables or dimensions (Holling, 2001): the potential for change of a system that is its "wealth" or "capital"; the internal controllability of a system corresponding to the degree of flexibility or rigidity towards perturbations or connectedness between internal controlling variables and processes; and the resilience of adaptive capacity of a system to unexpected or unpredictable shocks. Ecosystems are dynamic and thus management has to be flexible and thus adaptive, working atscales that are compatible with critical phases. The key for enhancing system resilience and to adapt to a changing social or natural ecology is to learn from past experiences (Redman, 2005). The Resilience concept has been defined over 40 years ago by Holling (1973) in his seminal paper Resilience and stability of ecological systems. This duality between resilience and stability can be seen as the relation that explains the adaptive spectrum (Smit and Wandel, 2006) between extinction and persistence of an ecological human system (or any other type of system, according to Holling). While Resilience is a measure of the ability that the systems have to absorb changes while persisting, "Stability is the ability that a certain system has to return to an equilibrium state after a temporary disturbance" (Holling, 1973, pp. 17).

Human adaptations, primarily prehistoric ones, lived frequently on the brink of extinction and, thus, the concept of Resilience seems to be highly appropriate for application in the 
interpretation of moments of rapid cultural changes, still, as Butzer (2012) as stated, "the fact that cultures develop unique situational constraints is critical in understanding the processes of resilience" (Butzer, 2012:3638). Walker et al. (2004) defined Resilience as the capacity of a system to absorb disturbance and re-organize while enduring changes and simultaneously keeping some of the previous traits. Adger (2000), on the other hand, focused more on a social perspective and defined Resilience as the human social ability to endure external shocks. An important sister concept to Resilience is that of Robustness, defined by Carlson and Doyle (2002) and later used by Anderies et al. (2004): Robustness is seen as the maintenance of some desired system characteristics despite fluctuations in the behavior of its component parts or its environment. The important factor is the relationship between the internal simplicity of the system or organism and its robustness. In fact, and according to Anderies et al. (2004) Robustness is better applied to the costbenefit trade-offs associated with systems designed to cope with uncertainty.

Folke in his 2006 paper focusing on the history of the definition and application of the Resilience concept has argued that Resilience is not only about robusticity or persistency of certain traits in a system - it is, and perhaps more importantly, about the opportunities for dynamic reconfiguration of the processes and structures that result from disturbance (Folke, 2006). This process causes a renewal of the system and the possible development of very different paths - what Smit andWandel (2006) have called adaptive capacity that can shape continuous development while ecological abrupt disruptions are taking place. Resilience Theory is now an important tool for the study of Prehistoric Archaeology (e.g., Bicho, 2013; Haws, 2012; Redman and Kinzig, 2003). The main reasons are that: "1) change is episodic, not continuous or gradual, and characterized by slow accumulation punctuated by abrupt release and reorganization; 2) spatial and temporal ecosystem attributes are patchy and discontinuous; 3 ) ecosystems do not remain at equilibrium but have multiple equilibria with destabilizing forces that create and maintain diversity, flexibility and opportunity and stabilizing ones that maintain productivity, fixed capital and memory" (Haws, 2012). The case of the Mesolithic-Neolithic transition in central Portugal seems to be a perfect case study to apply Resilience Theory and to understand the importance of Resilience in human adaptations in moments of potential extinction: a major social and economic disturbance allied to the apparent biological replacement are at the base of the process in the Muge Mesolithic-Neolithic replacement; nevertheless, resilience phenomena seem to have surfaced after the period of cultural ecological rupture, resulting in a new reconfiguration of the social order, combining both genetic and cultural elements of both human populations.

It has been argued that there are two types of resilience: engineering resilience and ecological resilience, also known as Robustness in the case of social-ecological systems: "Engineering resilience assumes that ecological systems exist close to a stable steadystate and measures the ability of a system to return to this steady state following a perturbation (Pimm, 1984). Ecological resilience emphasizes conditions far from any stable steady-state, where perturbations can shift a system from one regime of behavior to another i.e., to another stability domain (Holling,1973)" (Janssen and Anderies, 200746). In this paper, we are dealing with the latter, in a phase of major disruption with the disappearance of the Mesolithic way of life and the settling of a new social order and stability of the new technology of farming. 


\section{Mesolithic and Neolithic adaptations in Portuguese Estremadura}

The Muge shellmiddens were discovered in 1863 and since then Mesolithic has been an important topic in the study of prehistory in Portugal. The first excavations in Muge conducted by Carlos Ribeirooccurred in the same year of the discovery (Cardoso and Rolão, 2000; Rolão, 1999). The first results were published in 1865 by Pereira da Costa in collaboration with Ribeiro, referring the existence of a burial ground at the site of Cabeço da Arruda with at least 45 individuals, associated to an important collection of lithic artifacts, bone tools and fauna (Costa, 1865). Since then, various researchers (e.g., Mendes Correia, Jean Roche, José Rolão) excavating one or more of the three main middens in Muge (Moita do Sebastião, Cabeço da Arruda and Cabeço da Amoreira) found hundreds of human skeletons. Unfortunately, the main concern of many of those researchers was centered on the recovery of the human remains and, thus, the excavation procedures did not provide details on either horizontal or vertical provenience of materials recovered during excavation. Also, in most cases, the excavation was based on a simple three horizontal layer division of the 3-5 m thick deposits. The result is that, since most archaeological horizons are not horizontal, the provenience of all materials including human skeletons is mixed, faulty or erroneous. Mesolithic sites, dated from 8500 to 7000 cal BP in central Portugal, are known mostly from the Tagus and Sado valleys (Bicho, 1994; Carvalho, 2009). Nevertheless, there are a few sites near the coast (GutiérrezZugasti et al., 2011).

In general, the Mesolithic sites in central Portugal are open air locations - cave and rockshelters in the region have no evidence of human occupation between c. 8500 and 7500 cal BP. Although the sites from the Sado and Tagus valleys are usually both described as shellmiddens, they are very different types of sites, both in location and morphology. In the latter, the Muge sites are usually located on low to medium height terraces adjacent to the small Tagus tributaries. They are very large sites forming shellmounds mostly above ground with long and complex stratigraphies that reach between 3 and $5 \mathrm{~m}$ thick. They are usually circular to semi-circular in shape composed mostly of shell filled matrix (Aldeias and Bicho, 2016) resulting from many episodes of anthropic shell deposition.

The Sado sites are mostly below modern surface, composed of horizontal shell layers intercalated with sandy layers (Arias et al., 2015) and not nearly as thick as the Muge sites. The sites are on top of sandy terraces, frequently high above and away from the alluvial plain and in almost all cases directly related to the main valley.

The sites from both valleys are marked by the presence of frequent habitat features that include hearths, pits, post-holes and pavements. The most important features are human burials, characterized by various funerary patterns (Peyroteo Stjerna, 2016; Umbelino et al., 2015).

From a technological point of view, the Mesolithic of central Portugal is marked by the extensive use of bladelet technology to produce a wide range of geometric microliths including triangles (Fig. 2), crescents, and trapezes, as well as a series of small, but very standardized backed bladelets. Body ornaments are diversified, made on burnt clay, red deer teeth and shell, mostly with a fluviatile provenience (André and Bicho, 2016) and rarer marine species.

Isotopic data indicates that human diet during the Mesolithic was based on both terrestrial and marine resources, with frequencies of marine diet ranging from c. $25 \%$ in most of Sado sites (Guiry et al., 2015; Peyroteo Stjerna, 2016; Umbelino, 2006), while in the Muge region the marine diet is always above c. $50 \%$, reaching in at least one case c. $70 \%$ (Bicho et al., 2015). 


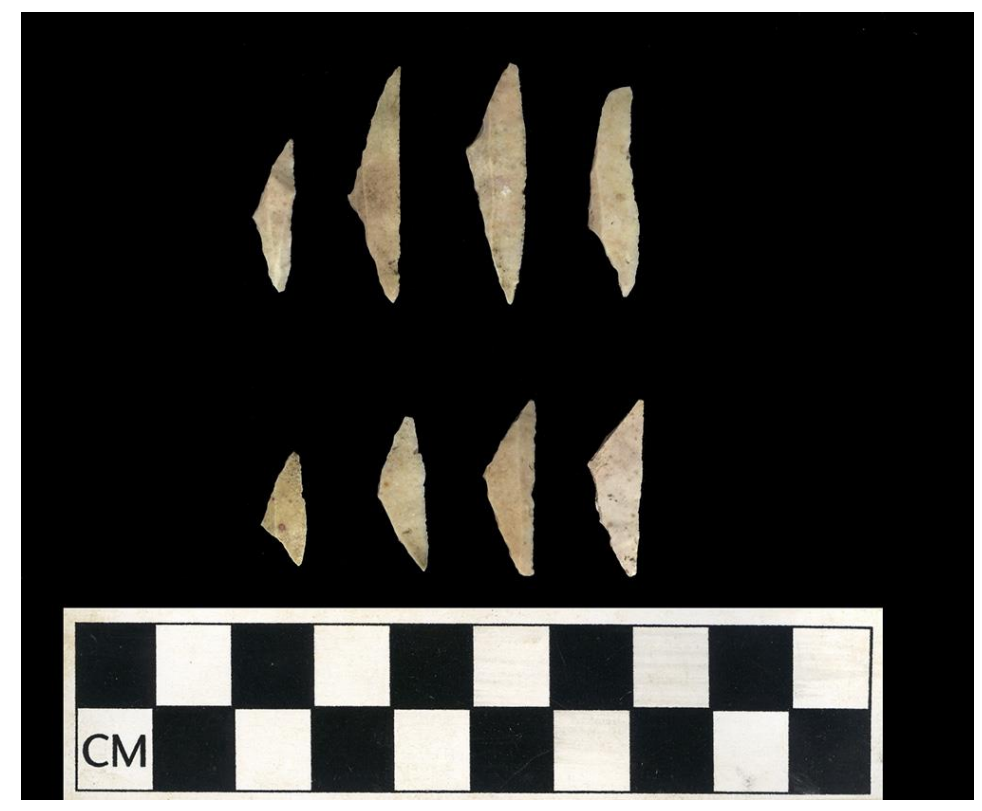

Fig. 2. Mesolithic Geometrics from the Cabeço da Amoreira shellmound, layer 1.

The earliest Neolithic sites in Portugal are known from Algarve and Estremadura (Carvalho, 2010). The evidence for Neolithic communities in Estremadura (Fig. 3) is dated as early as c. 7600 cal BP (Carvalho, 2010) in sites such as Caldeirão and Almonda caves, or the rockshelter of Pena d'Água (Carvalho, 2003, 2007, 2009). According to Zilhão (1993) and Carvalho (2003, 2007) these were likely exogenous groups that arrived from the Mediterranean, bordering the southern Portuguese Atlantic coast, in what today is known as a leap-frog colonization, bringing a full Neolithic package with ceramics (some decorated with Cardial technique), domesticated cereals and animals, and polished stone. Settlement seems to be marked by the use of open air locations, as well as rockshelter, while caves were frequently used as funerary contexts. An important aspect is that there are very few sites with Mesolithic and Neolithic occupations in central Portugal with the exception of Cabeço da Amoreira and possibly Cabeço da Arruda, both shellmounds in Muge.

Neolithic stone tool technology included heat treatment to produce very standardized bladelets and blades that were transformed by backing. Geometric microliths were also produced (Carvalho, 2007; Diniz, 2007), but not nearly as homogenous and finely finished as in the previous periods. The tendency was to produce smaller crescents and triangles, while the trapezes were usually wider than those produced during the Mesolithic. Funerary contexts are found inside caves, where human bodies were deposited, frequently in small groups. Human diet seems to be based mostly on terrestrial resources during the Neolithic in central and southern Portugal (Carvalho and Petchey, 2013; Umbelino et al., 2007; Umbelino, 2006).

\section{The Muge Mesolithic-Neolithic data}

In 2007 our team started a project in Muge centered on the site of Cabeço da Amoreira, one of the main shellmounds in Muge. Our project focused on a set of main ideas: the recovery of a full and detailed stratigraphy; the subsequent definition of a comprehensive chronology of the Muge shellmiddens and the establishment of occupation phases and their respective material culture characteristics; the understanding of intra-site spatial organization and the definition of site function, since due to their size, all sites were 


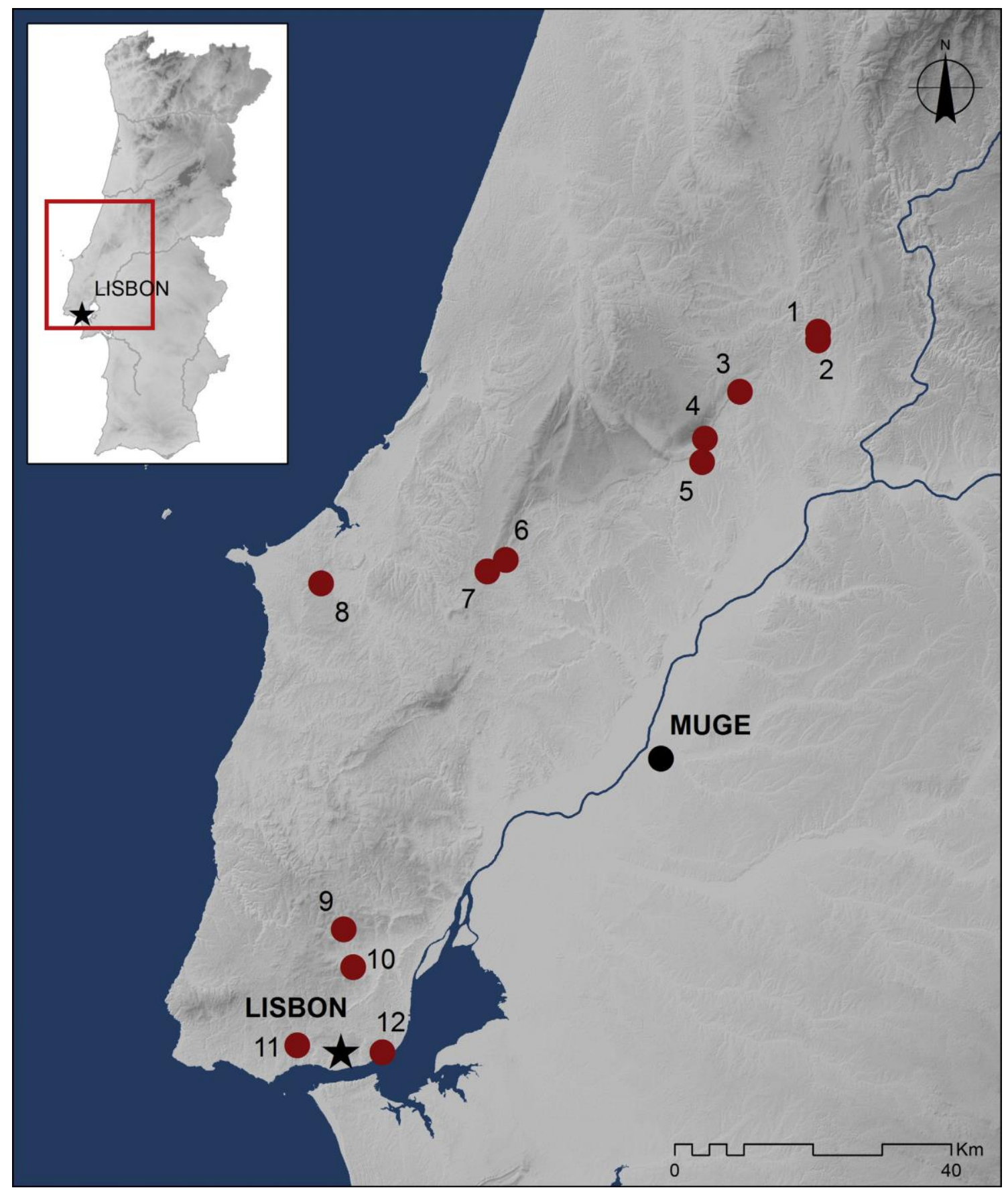

Fig. 3. Map of central Portugal with the location of the early Neolithic sites listed in Table 5. 1. N.a S.a das Lapas; 2. Caldeirão; 3. Pena d'Água; 4. Algar do Picoto; 5. Almonda; 6. C.P.M.IIIS; 7. Bocas; 8. Encosta de Sant'Ana; 9. Casa da Moura; 10. Correio-Mor; 11. Pedreira de Salemas; 12. Carrascal.

previously considered residential base camps; and the study of the human impact on the local landscape including what Zvelebil (2003) called an acculturated landscape. Seven years of research have provided a key shift in the interpretation of the Muge shellmiddens. The major outcome was the evidence of the consolidation of the so-called Complex Hunter-Gatherer system (e.g., Bailey and Milner, 2002; Erlandson, 2001) during the construction of the shellmounds in Muge (Aldeias and Bicho, 2016; Bicho, 2009; Bicho et al., 2013, 2015; Gonçalves et al., 2014). 
This perspective was supported by data coming mostly from the development of excavations at Cabeço da Amoreira (Fig. 4), whose results have also permitted: to establish an absolute chronology for the time-span of shellmidden deposition, now dated to be between c. 8000 and 7350 cal BP (Table 1); to identify a basal occupation,

below the shell layers, with both residential and burial function and represented the beginning of the human occupation in Muge (Bicho et al., 2013); the definition of at least three different phases of funerary activity in the mound, respectively at c. 8000, 7500 and after 7300 cal BP; the recognition, on the shellmound, of a top layer composed, mostly, of small pebbles and fire-cracked rocks, interpreted as a cairn as a potential protective cover for the burial grounds below (Bicho et al., 2013), marked by later intrusions for the deposition of Neolithic burials; and to identify previously unreferenced "shell-free" archaeological loci, including Neolithic occupations, in an peripheral area to the mound itself (Bicho et al., 2011).

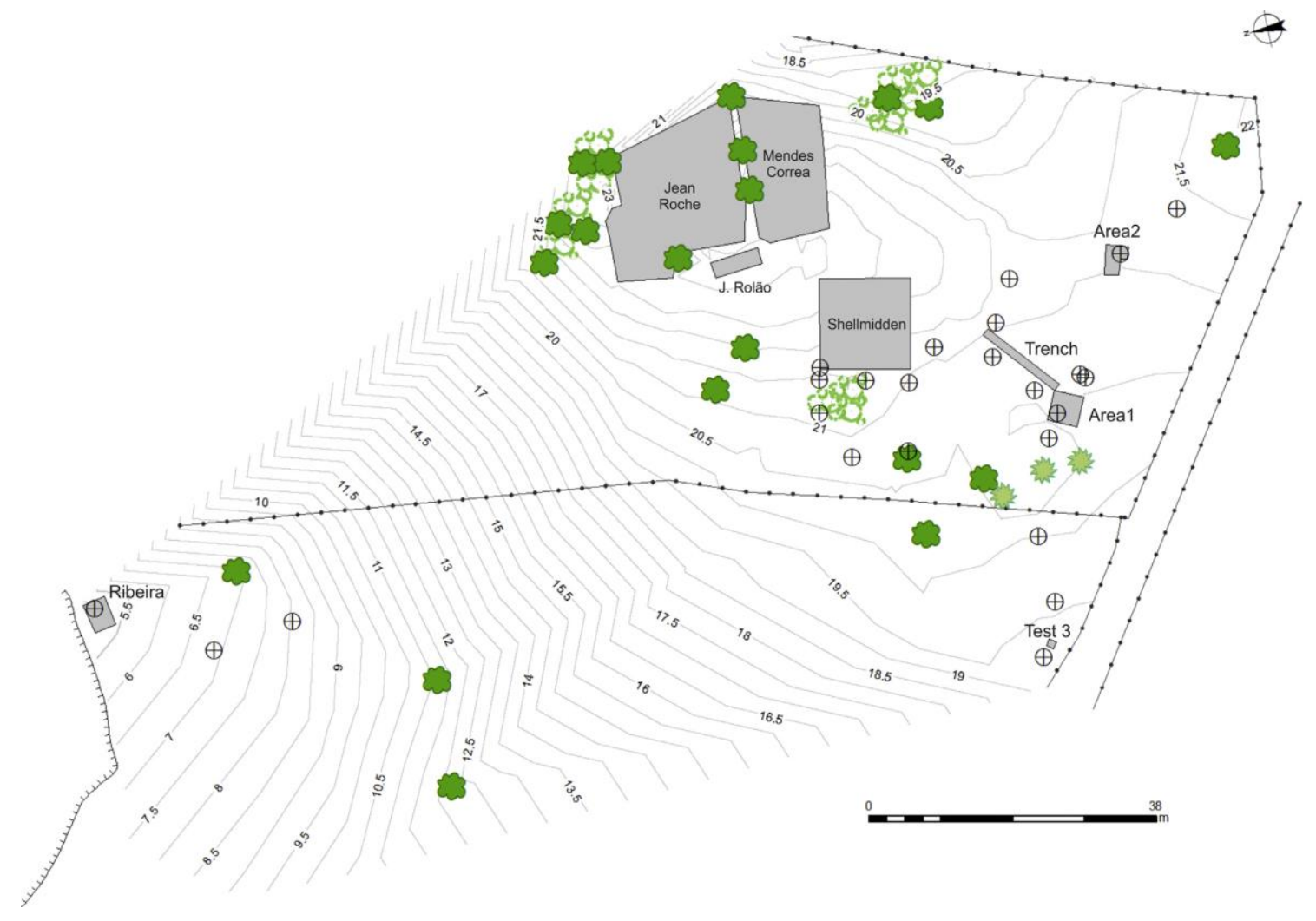

Fig. 4. Plan view of the excavation and testing areas in Cabeço da Amoreira. 
Table 1. AMS results for Cabeço da Amoreira, Muge.

\begin{tabular}{|c|c|c|c|c|c|c|c|}
\hline Provenience & Mound Area & Lab code & Material & Date BP & cal BP 2б & Context & Reference \\
\hline Layer 3 & - & Wk-42845 & Alnus & $2064 \pm 20$ & $2115-1950$ & Ribeira & This paper \\
\hline Layer 5 & - & Wk-42846 & Erica arborea & $2777 \pm 20$ & $2945-2875$ & Ribeira & This paper \\
\hline Layer 6 & - & Wk-42847 & Ericaceae & $4372 \pm 20$ & $5030-4865$ & Ribeira & This paper \\
\hline Layer 7 & - & Wk-42848 & Erica arborea & $4376 \pm 20$ & $5030-4865$ & Ribeira & This paper \\
\hline Multiple burial CAM-01-01 & José Rolão & Wk-26796 & Homo & $6329 \pm 40$ & $7145-6859$ & Cairn & Bicho et al., 2011 \\
\hline Multiple burial CAM-01-01 & José Rolão & TO-10225 & Homo & $6550 \pm 70$ & $7572-7323$ & Cairn & Rocksandic, 2006 \\
\hline Multiple burial CAM-01-01 & Jean Roche & TO-10218 & Homo & $6630 \pm 60$ & $7435-7184$ & Cairn & Rocksandic, 2006 \\
\hline Camada 3(=layer 1b) & José Rolão & Sac-2079 & Shell & $7050 \pm 45$ & $7544-7302$ & Cairn & Martins et al, 2008 \\
\hline Camada 3(=layer 1b) & José Rolão & Sac-2080 & Shell & $7080 \pm 80$ & $7595-7273$ & Cairn & Martins et al, 2008 \\
\hline Camada $1 b$ & Shellmidden & Wk-26798 & Cerastoderma edule & $7145 \pm 37$ & $7591-7410$ & Cairn & Bicho et al., 2011 \\
\hline Camada 3(=layer 1b) & José Rolão & Sac-2023 & Shell & $7260 \pm 60$ & $7740-7458$ & Cairn & Martins et al, 2008 \\
\hline Layer $1 b$ & Shellmidden & Wk-26797 & Cerastoderma edule & $7291 \pm 35$ & $7510-7730$ & Cairn & Bicho et al., 2011 \\
\hline Burial 2011.2 - Layer 2b & Shellmidden & Wk-32142 & Homo & $6910 \pm 40$ & $7566-7429$ & Shell layers & Bicho et al. 2013 \\
\hline Burial 2012.3 - Layer 2b & Shellmidden & Wk-35718 & Homo & $7056 \pm 34$ & $7665-7520$ & Shell layers & Price 2015 \\
\hline Skeleton 7 & Jean Roche & Beta-127450 & Homo & $6850 \pm 40$ & $7564-7429$ & Shell layers & Meiklejohn, et al, \\
\hline layer 22 & North cut & Wk-30674 & Scrobicularia plana & $7356 \pm 33$ & $7796-7573$ & Shell layers & Bicho et al, 2011 \\
\hline Layer 22 & West cut 2 & Wk-30672 & Scrobicularia plana & $7360 \pm 34$ & $7803-7576$ & Shell layers & Bicho et al, 2011 \\
\hline Layer B & West cut & Wk-28050 & Scrobicularia plana & $7377 \pm 33$ & $7820-7590$ & Shell layers & Bicho et al., 2011 \\
\hline Layer C & West cut & Wk-28049 & Scrobicularia plana & $7193 \pm 33$ & $7900-7658$ & Shell layers & Bicho et al., 2011 \\
\hline Layer D & West cut & Wk-28048 & Scrobicularia plana & $7445 \pm 33$ & $7630-7435$ & Shell layers & Bicho et al., 2011 \\
\hline Layer F & West cut & Wk-28047 & Scrobicularia plana & $7376 \pm 34$ & $7820-7589$ & Shell layers & Bicho et al., 2011 \\
\hline Layer G & West cut & Wk-28046 & Scrobicularia plana & $7368 \pm 39$ & $7816-7580$ & Shell layers & Bicho et al., 2011 \\
\hline Layer H & West cut & Wk-28045 & Scrobicularia plana & $7315 \pm 35$ & $7767-7548$ & Shell layers & Bicho et al., 2011 \\
\hline Layer H & West cut & Wk-28044 & Scrobicularia plana & $7311 \pm 34$ & $7762-7545$ & Shell layers & Bicho et al., 2011 \\
\hline Layer I & West cut & Wk-28043 & Scrobicularia plana & $7273 \pm 34$ & $7710-7499$ & Shell layers & Bicho et al., 2011 \\
\hline Layer J & West cut & Wk-28042 & Scrobicularia plana & $7323-48$ & $7793-7537$ & Shell layers & Bicho et al., 2011 \\
\hline Layer K & West cut & Wk-28041 & Scrobicularia plana & $7384 \pm 48$ & $7843-7580$ & Shell layers & Bicho et al., 2011 \\
\hline Layer K & West cut & Wk-28040 & Scrobicularia plana & $7305 \pm 48$ & $7770-7515$ & Shell layers & Bicho et al., 2011 \\
\hline Layer L & West cut & Wk-28039 & Scrobicularia plana & $7395 \pm 48$ & $7855-7587$ & Shell layers & Bicho et al., 2011 \\
\hline Layer M & West cut & Wk-28038 & Scrobicularia plana & $7365 \pm 49$ & $7826-7570$ & Shell layers & Bicho et al., 2011 \\
\hline Layer N & West cut & Wk-28037 & Scrobicularia plana & $7307 \pm 48$ & $7774-7516$ & Shell layers & Bicho et al., 2011 \\
\hline Layer O & West cut & Wk-28036 & Scrobicularia plana & $7251 \pm 48$ & $7706-7463$ & Shell layers & Bicho et al., 2011 \\
\hline Layer O & West cut & Wk-28035 & Scrobicularia plana & $7395 \pm 48$ & $7855-7587$ & Shell layers & Bicho et al., 2011 \\
\hline Layer P & West cut & Wk-28034 & Scrobicularia plana & $7370 \pm 48$ & $7828-7572$ & Shell layers & Bicho et al., 2011 \\
\hline Layer 2 & West cut 2 & Wk-30671 & Scrobicularia plana & $7417 \pm 34$ & $7853-7614$ & Shell layers & Bicho et al, 2011 \\
\hline Layer 2 & North cut & Wk-30673 & Scrobicularia plana & $7406 \pm 32$ & $7846-7613$ & Shell layers & Bicho et al, 2011 \\
\hline Layer 4 & Animal 1 & WK-42844 & Red deer & $6633 \pm 20$ & $7570-7480$ & Base of shell layers & This paper \\
\hline Layer W & Main area & WK-42841 & Pinus & $7051 \pm 22$ & $7940-7840$ & Below of shell layers & This paper \\
\hline Layer Z & Main area & Wk-40699 & Cerastoderma edule & $7281 \pm 20$ & $7810-7670$ & Below the shell layers & This paper \\
\hline Layer Z & Main area & Wk-40700 & Charcoal & $7197 \pm 25$ & $8045-7960$ & Below the shell layers & This paper \\
\hline Layer Q & West cut & Wk-28033 & Scrobicularia plana & $7479 \pm 48$ & $7930-7668$ & Below the shell layers & Bicho et al., 2011 \\
\hline Burial 2011.1 & Jean Roche & Wk-32143 & Homo & $7132 \pm 41$ & $7785-7594$ & Below the shell layers & This paper \\
\hline Burial CAM-00-01 & Jean Roche & TO-11819-R & Homo & $7300 \pm 80$ & $8015-7695$ & Below the shell layers & Rocksandic, 2006 \\
\hline Hearth 1 & West cut & UGAMS-7196 & Charcoal & $6990 \pm 30$ & $7931-7736$ & Below the shell layers & Bicho et al., 2011 \\
\hline Pit 1 & West cut & UGAMS-7197 & Scrobicularia plana & $7450 \pm 30$ & $7899-7663$ & Below the shell layers & Bicho et al., 2011 \\
\hline
\end{tabular}




\subsection{Funerary contexts at Cabeço da Amoreira}

Archaeological research took place in the Cabeço da Amoreira shellmound in the 19th century (PI e Carlos Ribeiro and Pereira da Costa), early 1930's (PI - Mendes Corrêa),1960's (PI - Jean Roche and Veiga Ferreira), 2000_03 (PI - José Rolão), and finally from 2008 to 2014 (PI - Nuno Bicho). Human remains were found and collected by all teams in a total of at least 35 individuals (11-12 from 1930's +17 from the 1960's $+4 / 5$ from $2000+3$ from 2011 to 12 ).

Dating of the human remains suggests that there are 3 main phases of funerary episodes (Table 1), as stated above. The first human burials took place during the initial occupational phase of the location, previous to the building up of the mound (Aldeias and Bicho, 2016; Bicho et al., 2013). The second burial episode was after the deposition of the shell layers, some 7500 years ago, just prior to the layering of the cairn. The last human burial phase, fully Neolithic in time, corresponds to a disturbance of the cairn with the burial of a possible succession of interment episodes, all in the same exact spot forming the only example of a multiple burial with at least 3 individuals (Bicho et al., 2011, 2013; Ferreira et al., 2015; Rocksandic, 2006; Umbelino et al., 2015). These three individuals also present the lowest percentage of marine diet in Cabeço da Amoreira: while all other skeletons with known proveniences and older absolute dates have results between c. 50 and $72 \%$ of marine diet, the three individuals buried later in the cairn show results between c. $46 \%$ of marine diet and full terrestrial diet (Table 2; Fig. 5). Also interesting is that a recent paper on Strontium isotopic results from Muge (Price, 2015), which includes a set of seven individuals from the region, shows that the skeleton with a terrestrial diet from the multiple burial is the only skeleton with an exogenous origin.

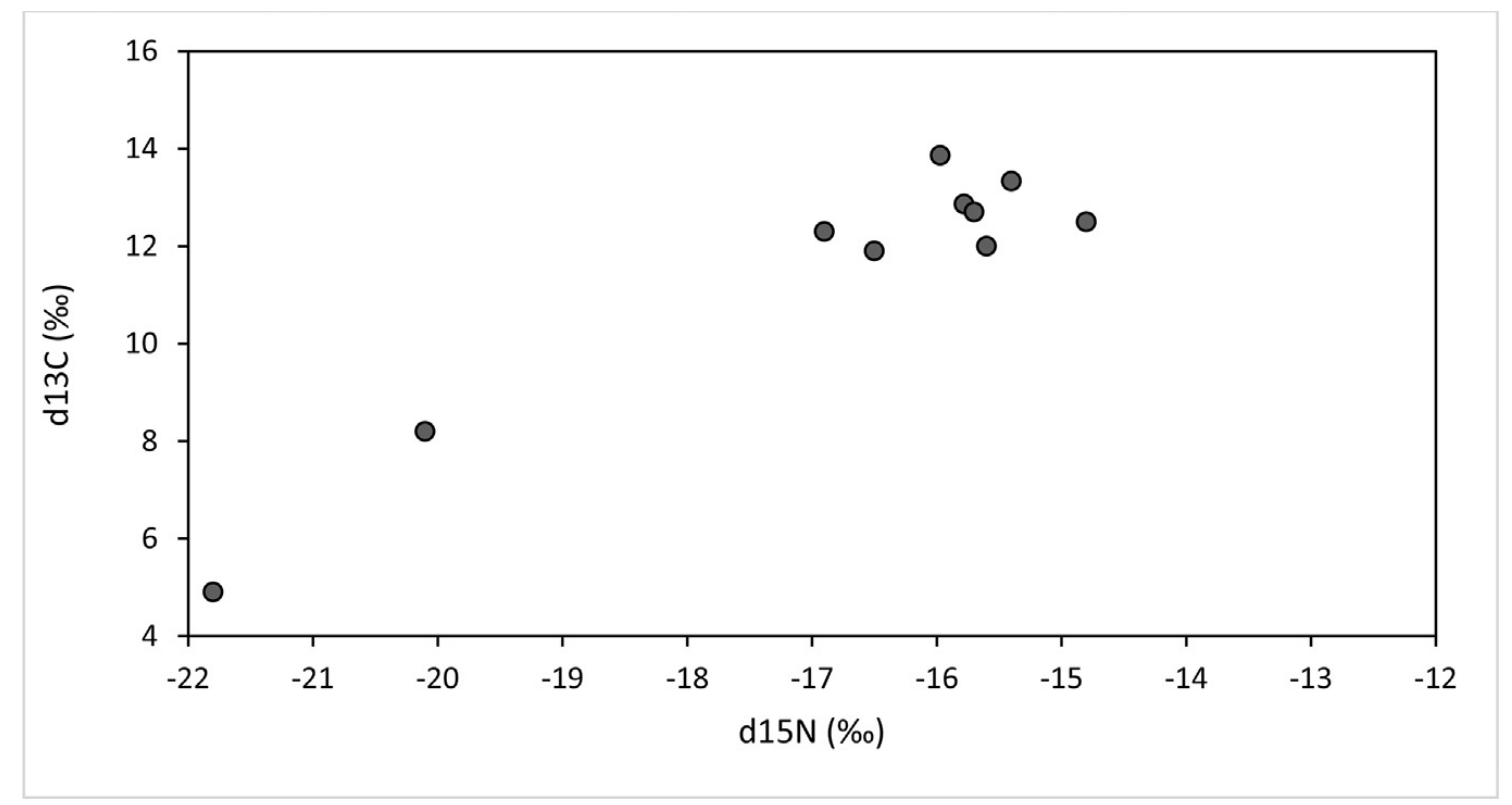

Fig. 5. Plot with the $\mathrm{d} 13 \mathrm{C} / \mathrm{d} 15 \mathrm{~N}$ isotopic data for the human skeletons from Muge. 
Table 2. \% of marine diet in the human skeletons of Cabeço da Amoreira*.

\begin{tabular}{|c|c|c|c|c|c|c|c|c|}
\hline Skeleton & Context & Lab code & Date BP & 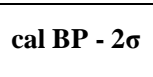 & $\delta^{13} \mathrm{C}(\%)$ & $\begin{array}{l}\delta^{15} \mathrm{~N} \\
(\% 0)\end{array}$ & $\%$ Marine diet & ${ }^{87} \mathrm{Sr}$ \\
\hline Multiple burial CAM-01-01 & Cairn & Wk- 26796 & $6329 \pm 40$ & $7145-6860$ & -16.9 & 12.3 & 46 & \\
\hline Multiple burial CAM-01-01 & Cairn & TO-10218 & $6630 \pm 60$ & $7435-7210$ & -17.1 & - & 42 & \\
\hline \multirow{2}{*}{ Multiple burial CAM-01-01 } & Cairn & TO-10225 & $6550 \pm 70$ & $7570-7325$ & -20.1 & 8.2 & 0 & 0.7140 \\
\hline & & & & & -21.8 & 4.9 & 0 & \\
\hline Skeleton 7 & $?$ & Beta- 127450 & $6850 \pm 40$ & $7565-7430$ & -16.5 & 11.9 & 48 & \\
\hline Burial 2011.2 & Layer $2 b$ & Wk-32142 & $6910 \pm 40$ & $7565-7430$ & -15.78 & 12.86 & 58 & 0.7101 \\
\hline Burial 2012.3 & Layer $2 b$ & Wk-35718 & $7056 \pm 34$ & $7665-7520$ & -15.4 & 13.33 & 62 & 0.7096 \\
\hline CAM-00-01 & basal & TO-11819-R & $7300 \pm 80$ & $8015-7695$ & -16.3 & - & 50 & \\
\hline Burial 2011.1 & Basal & Wk-32143 & $7132 \pm 41$ & $7785-7595$ & -15.97 & 13.86 & 56 & \\
\hline Skeleton 4 & & - & - & - & -15.7 & 12.7 & 59 & \\
\hline Skeleton 6 & & - & - & - & -14.8 & 12.5 & 69 & \\
\hline Skeleton 8 & & - & - & - & -15.6 & 12 & 60 & \\
\hline
\end{tabular}

* calibration with OxCal 4.2 (Ramsey, 1995) with IntCal13 curve (Reimer et al., 2013). $\Delta \mathrm{R}$ value of $140 \pm 40$ from Martins et al. (2008). 


\subsection{Neolithic occupations at Cabeço da Amoreira}

Up to 2008, all shellmounds in Muge were thought to be single and isolated large residential sites (Rolão, 1999). When our team started to work in Cabeço da Amoreira, one of the first tasks was to auger the area around the mound to define its limits. A series of auger tests (Fig. 4) were placed from the outer rim towards the center of the mound as well as a few tests outside the main field where the site is located (Bicho et al., 2011). This work produced important results, since we were able to find a group of new loci within a hundred meters from the shellmound. It should be noted that we did not systematic testing around the site and all the augering was no further than $100 \mathrm{~m}$ from the center of the mound.

Area 1 (Fig. 4) is marked by the presence of at least 3 archaeological horizons. The bottom one is a Mesolithic occupation and corresponds stratigraphically to the end of the deposition of the cairn. The two overlaying horizons have a fairly large ceramic assemblage with diverse decorated sherds (boquique technique and a single cardial decorated sherd) and are likely evolved early Neolithic (Table 3; Fig. 6). A similar stratigraphic sequence can be found in the Trench area (Fig. 7), where there is a direct connection with the southern edge of the mound (André and Bicho, 2016; Bicho et al., 2011; Cascalheira et al., 2015).

Area 2 presents a similar sequence, but is characterized by a Mesolithic and a single ceramic horizon, with unknown chronology. Further to the west, a single $1 \mathrm{sq}$. meter test was placed in a locus where ceramics were found some $80 \mathrm{~cm}$ below surface. The test revealed a fairly rich ceramic deposit, possible dated to the Middle Neolithic.

The most important location is, however, the Ribeira locus. Although we have not yet reached the bottom of the sequence due to logistical problems (this is a wet context, since the area is on the river bank and a large portion of the sequence is below the water table), we have uncovered a series of archaeological horizons of which the lower one seems to be Early Neolithic, while the overlaying layers go from Late Neolithic to historical times (Table 4).

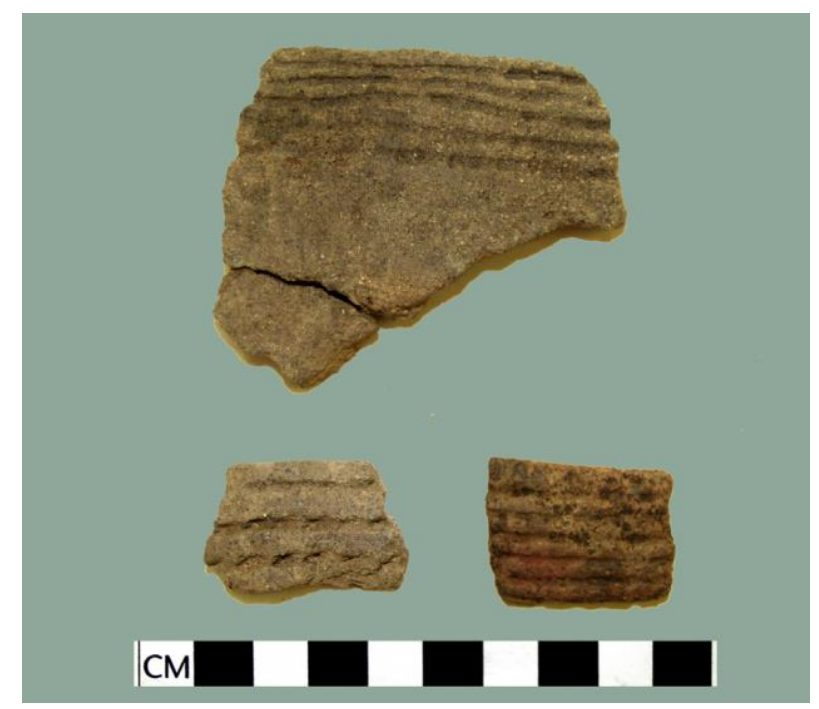

Fig. 6. Decorated ceramics from Area 1. 
Table 3. Neolithic ceramics from Cabeço da Amoreira.

\begin{tabular}{|c|c|c|}
\hline Archaeological areas & Contexts & Number of sherds \\
\hline \multicolumn{3}{|l|}{ Shellmidden } \\
\hline & Top layers (1/2) & 94 \\
\hline \multicolumn{3}{|l|}{ Trench } \\
\hline & 11 & 1 \\
\hline & 9 & 3 \\
\hline & 8 & 5 \\
\hline & 7 & 5 \\
\hline & 6 & 17 \\
\hline & 5 & 14 \\
\hline & 4 & 18 \\
\hline & 3 & 42 \\
\hline & 2 & 20 \\
\hline & 1 & 13 \\
\hline \multicolumn{3}{|l|}{ Area 1} \\
\hline & Horizon 1 & 24 \\
\hline & Horizon 2 & 155 \\
\hline & Horizon $2 b$ & 108 \\
\hline \multicolumn{3}{|l|}{ Area 2} \\
\hline & Horizon $1 / 2$ & 34 \\
\hline \multicolumn{3}{|l|}{ Area 3} \\
\hline & Horizon 1 & 45 \\
\hline \multicolumn{3}{|l|}{ Riverbank } \\
\hline & Layer 5 & 85 \\
\hline & Layer 6 & 208 \\
\hline & Layer 7 & 135 \\
\hline & Layer 8 & 1 \\
\hline TOTAL & & 1027 \\
\hline
\end{tabular}

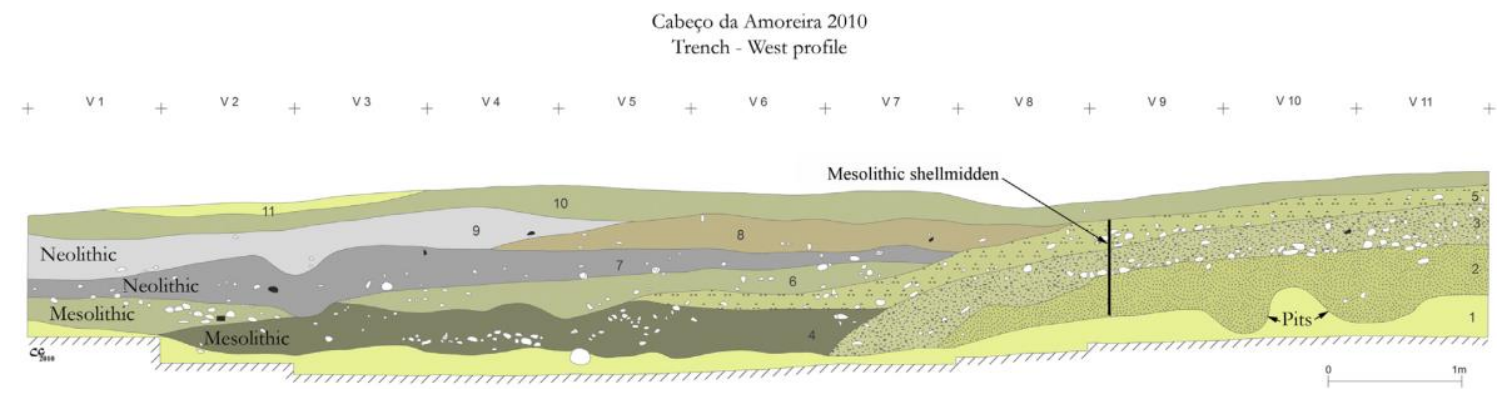

Fig. 7. West cut of the Trench area. 
Table 4. Summary of occupations in each loci of Cabeço da Amoreira.

\begin{tabular}{lllllll}
\hline & Mound & Area 1 & Trench & Area 2 & Test 1 & Ribeira \\
\hline Copper Age & & & & & & $\sqrt{ }$ \\
Middle Neolithic & & $\sqrt{ }$ & $\sqrt{ }$ & $?$ & & $\sqrt{ }$ \\
Early Neolithic & $\sqrt{ }$ & $\sqrt{ }$ & $\sqrt{ }$ & $\sqrt{ }$ & & $?$ \\
Mesolithic & $\sqrt{ }$ & $\sqrt{ }$ & $\sqrt{ }$ & & \\
\hline
\end{tabular}

\section{Discussion}

The traditional view on the emergence of Neolithic in central Portugal is that there was a full switch from a hunter-gatherer-fishing economy to a new food producing system with the introduction of agriculture and pastoralism (Carvalho, 2003, 2007; Zilhão, 1993). This was accomplished by the so called leap-frog colonization (Zilhão, 1993) and the establishment of a new exogenous population in coastal and inland areas free from a direct influence of Mesolithic populations from the Muge region, that used the Tagus river valley as the main resource origin and likely as a main pathway. Still, at the regional level, most likely there was some level of competition for the terrestrial resources between the two human groups.

The interesting aspect in the last 3 decades of research is that there has been very little discussion on the fate of the Mesolithic populations - the general perspective was that the Neolithic settlements in Portuguese Estremadura (as in Algarve) were "Neolithic enclaves" (Carvalho, 2010; Zilhão, 2000, 2001) with little or no contact with the Mesolithic population from the Tagus valley (Carvalho, 2010). In fact, Zilhão (2001:14185) has stated "This prediction is met in the archaeological record by the "enclave"' nature of early Neolithic territories in littoral-central Portugal, which occupy areas previously uninhabited by late Mesolithic hunter-gatherers. The latter continue to thrive in their own territories for some 500 years after initial Neolithic settlement, but contrasts in material culture, economy, nutrition, and mortuary behavior remain unchanged throughout this period. Neolithic sites feature pottery, polished hand axes, and heat pretreatment of flint, which are absent altogether from the Mesolithic, as are domesticates. Neolithic skeletons feature isotopic signatures of a fully terrestrial diet, whereas Mesolithic ones indicate a 50\% marine component. Neolithic people are buried in special-purpose collective funerary sites, whereas Mesolithic people are buried individually in habitation sites and have never been found carrying exclusively Neolithic body ornaments (tear-shaped Glycymeris beads, pierced red deer canines, and bone beads imitating them)".

New data from Cabeço da Amoreira largely contradict the traditional model supplied by Zilhão (2001, 2000) for the Portuguese Estremadura:

1. There is a perpetuation in settlement in the Cabeço da Amoreira shellmound by Neolithic people;

2. Although there is no absolute dating, it seems that in the direct surroundings of the mound there was a continuous occupation from the Mesolithic to the Neolithic, with the presence, sometimes in the same loci, of both Mesolithic and Neolithic horizons without any stratigraphic interruption;

3. Neolithic impressed ceramics, including very rare examples of Cardial ware, are present in various of those Cabeço da Amoreira loci, directly above the Mesolithic layers and within the top few centimeters of the Cairn (although these have been interpreted as mixing since the absolute dating of the cairn indicates that this was built at the same time of the arrival of the first Neolithic populations to the region);

4. Cabeço da Amoreira was used as burial grounds for both Mesolithic and Neolithic people; 
5. At least one of the human skeletons buried in the cairn and dated to Neolithic times is coming from a different region outside of the Muge region as indicated by the Strontium results. The same skeleton show evidences that the diet was based solely on terrestrial resources, while those two other individuals had a partial marine diet, although not as extensive as the previous local hunter-gatherers;

6 . The context where this skeleton was found is a multiple burial with at least 3 different individuals, corresponding to a change in the Mesolithic funerary patterns seen in the previous two burial phases in the mound;

7. Although not in direct association with human burials, there are a few perforated red deer teeth in the Mesolithic layers similar to those said by Zilhão (2001) to be typical Neolithic material culture.

The site chronology and stratigraphy seem to present two phases without any clear break: a first phase of contemporaneity between the Mesolithic population and the arrival to Portuguese Estremadura of the first Neolithic populations (Table 5) that settled the earliest coastal and inland enclaves in the highlands of the region; a second phase when early Neolithic populations started to use the Cabeço da Amoreira mound directly after the last Mesolithic contexts. This second phase, probably corresponding to Phase 2 (i.e., c. 7400-7000 cal BP) defined by Carvalho (2010), seems to correspond to the integration of the two populations, both at the genetic and cultural level e not only the traditional Mesolithic burial grounds in the Cabeço da Amoreira mound were used in sequence, but the whole vicinity of the site was occupied during the Neolithic and in many instances directly above in the same loci that the Mesolithic population had used before.

There are clear indicators in terms of site function of Cabeço da Amoreira, both funerary and residential as well as in some of the material culture that indicates a clear and strong persistence between the Mesolithic and Neolithic cultural system. Human mitochondrial DNA evidence from both Moita do Sebastião and Cabeço da Arruda Mesolithic skeletons (Fernández et al., 2010) and the Neolithic cave site of Algar do Bom Santo (Estremadura) (Carvalho et al., 2015) also confirms the linkage with the presence of evidence of genetic continuity between the local Mesolithic population and the later Neolithic people.

Albeit a mere coincidence, one can notice the clear similarity that exists between the Muge mounds and the posterior mounds (so called mamoas in Portuguese) that cover the later Neolithic dolmens in most of Portugal. While in the latter case, there is a megalithic stone structure within the mound, the aim is the same in both cases - human burial. If one considers the architectural volumetry of both types of monuments can only conclude that they are very similar and, thus, it is possible that the Muge shellmounds are the conceptual origin for the Neolithic mounds that covered the dolmens.

Based on the data presented above, it can be argued (as a hypothesis to be tested) resilience was the main adaptive process that made possible the perpetuation of the Mesolithic culture and connected Mesolithic and Neolithic populations in central Portugal. Those elements, listed above, mostly within the social and symbolic realms offer an adaptive capacity to the changing social ecology with the introduction of domesticates and slow contraction of the Tagus estuarine settings with the high aquatic biomass that made available a very important amount of the dietary resources used until then. Using Redman's concept (Redman, 2005), learning experiences from the Mesolithic populations enhanced the resilience system that permitted to adapt to the rapidly changing social ecological systems of the greater Tagus basin, with the integration of both Mesolithic biological and cultural elements with the new Neolithic populations.

Most likely a series of stress factors impacted severely the local Mesolithic communities after 7600 years cal BP. The most important was the presence of the new markedly different both ethnically and technologically exogenous Neolithic people that likely 
Table 5. Neolithic dates from Estremadura.

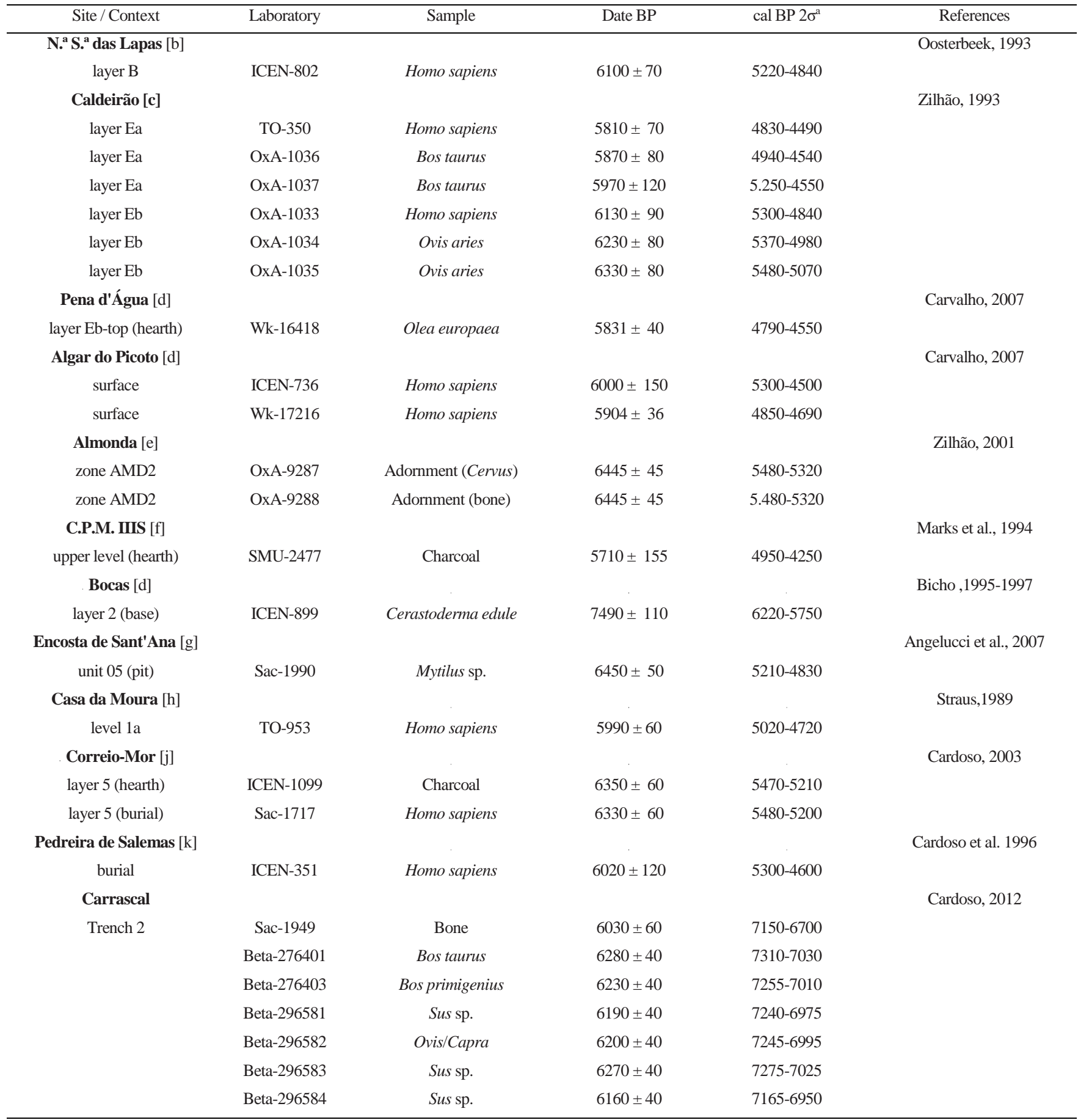

${ }^{a}$ calibration with OxCal 4.2 (Ramsey, 1995) with IntCal13 curve (Reimer et al., 2013). $\Delta \mathrm{R}$ value of $209 \pm 102$ from Carvalho and Petchey (2013). 
competed for the regional terrestrial resources (a major element on the diet and economy of the Muge Mesolithic hunter-gatherers). Not only prey species, such as red deer, horse, wild boar, aurochs and rabbits were hunted by the Neolithic people, the fact they were changing the vegetation cover with farming through slash and burn, also decreased the forest areas and thus impacted the number of available hunting resources. Although there are no available data, it is possible to hypothesize that the Neolithic groups also initiated a tenure rules of proprietary land management (Freeman and Anderies, 2012) that strongly conflicted with the territoriality based system of the Mesolithic groups (Bicho et al., 2013). The Neolithic economic stability coupled with a likely faster demographic growth may have been a mounting element of stress for the Mesolithic people from the Muge valley. Finally, and although a very slow process of degradation of the estuarine conditions after $7500 \mathrm{cal} \mathrm{BP}$, the possible reduction of the aquatic resources may have had an impact on the Mesolithic groups in the last couple hundred years of their regional settlement.

The regional Mesolithic demography, although stable for half a millennium, likely suffered with the arrival of the fast growing Neolithic groups. The incorporation of the Mesolithic people in the Neolithic farming groups corresponds to a successful resilience adaptive process to avoid the annihilation and extinction of the Mesolithic group - it is a perfect example of the "failure of local and regional social-ecological systems, at least temporarily, in order to learn how to improve the robustness properties of socialecological systems at larger scales" (Janssen and Anderies, 2007: 61).

\section{Conclusions}

In the last few decades the prevailing perspective for the development of farming and herding in central Portugal was that of a full human population replacement with the disappearance of both the hunter-gathering life way and the introduction of a complete Neolithic package that included domesticates (animal and cereals), ceramics, polished stone tools and a new human exogenous population that settled in the coastal and highlands of Portuguese Estremadura, away from the Tagus valley where the Mesolithic population lived. With the new data results from Muge, including the presence of the Neolithic loci, human burial contexts in Cabeço da Amoreira and their material culture, as well as indirect symbolic evidence, there seems to be evidence of cultural and human integration between the two populations. This is further confirmed by the presence of human mitochondrial DNA in Neolithic skeletons with haplogroups characteristic of the Muge Mesolithic populations (Carvalho et al., 2015; Fernández et al., 2010).

The deposition of the shellmounds and the cairn are perhaps the most interesting elements since, in addition to being virtually unique in the context of Mesolithic shellmiddens, they confirm the existence of different functions in a single location. It also confirms the pattern of continuity of site use from the Mesolithic to the Neolithic, already attested by the radiocarbon dates of some of the top-layer burials excavated through the cairn. These elements relaunch the debate on the cultural interactions and resilience forms between the last hunter-gatherers and the first farming communities of Central Portugal.

There was a partial overlap in the region of a few hundred years between the Muge Mesolithic and the early Neolithic populations in a first phase, followed by a second phase with the use of the location by a series of possible Evolved Early Neolithic and Middle Neolithic occupations at Cabeço da Amoreira, that confirms an assimilation of Mesolithic cultural traits by the Neolithic regional population. This cultural and ecological setting 
seems to confirm the idea of a resilient dynamic adaption to a strong and unexpected perturbation brought by the new exogenous Neolithic populations.

Within the Adaptive Cycle, the emergence of farming and herding in Central Portugal was perhaps a moment where resilience can be best seen and can be interpreted as the sequence from the release to the reorganization phase, a moment of major ecological and social upheaval and turmoil. The resilient adaptive process (against the extinction of the Muge Mesolithic group) was based on a symbiotic development between the learned Mesolithic past experiences (i.e., symbolic funerary and body decorative elements, site location and, perhaps, in a small scale, the use of aquatic resources) with the new technologies and population inflicting drastic disturbances to the previous fairly stable system.

Thus, the Tagus valley is the ideal setting to test the hypothesis of the resilient Mesolithic cultural matrix mixing and rising in the midst of the Neolithic of central Portugal. As stated above, it corresponds to the local failure of the Mesolithic hunter-gatherers-fisher social and economic system to greatly improve the robustness properties of new socialecological system of the future that is the Neolithic. The integration of the two populations likely combined a fast growing food producing economy with the exploitation of wild resources resulting in a rapid expanding demography coupled with an increasing territory of exploitation with the union of the land from both Mesolithic and Neolithic populations and the use of previous settlement locals. In addition, the resilient Mesolithic symbolic system, with the funerary rituals and complex architecture, enriched and stabilized the Neolithic ritual scheme possibly providing the original elements (the funerary mounds) for the megalithic development that took place during the Neolithic in central Portugal. Clearly, Resilience Theory and the concept of Robustness are the fundamental elements that allowed the development of a preliminary model for the understanding of the Mesolithic/Neolithic transition in central Portugal. While Resilience Theory has helped to explain cases where stability exists together with other farming populations (Rosen and Rivera-Collazo, 2012), in the present case study, the process of rapid integration is easily explained by Resilience Theory and perhaps can be used as an example for other identical processes of extinction of hunter-gatherer contexts across the world, Mesolithic or not.

\section{Acknowledgments}

Fundação para a Ciência e Tecnologia (Portugal) funded "The Last Hunter-gatherers in the Tagus Valley d The Muge Shellmiddens" (PTDC/HAH/64185/2006) and "The last hunter-gatherers of Muge (Portugal): the origins of social complexity (PTDC/HIS-ARQ/ $112156 / 2009)$ )" that provided the data presented here.

We would like to thank various anonymous reviewers that helped to greatly improve the paper. Also we want to thank Goa Borrek and the Turnitin Company (Oakland, California) for assisting on originality check and revision assistant. We would also like to thank Casa Cadaval, owner of the land where Cabeço da Amoreira is located, that along the years has helped the team during the field seasons, as well the Câmara Municipal de Salvaterra de Magos that has also helped with the logistics of field work.

\section{References}

Adger, W.N., 2000. Social and ecological resilience: are they related? Prog. Hum. Geogr. 24, $347 \mathrm{e} 364$.

Aldeias, V., Bicho, N., 2016. Embedded Behavior: human activities and the construction of the Mesolithic shellmoundof Cabeço da Amoreira (Muge, Portugal). Geoarchaeology. http://dx.doi.org/10.1002/gea.21573. 
Anderies, J.M., Janssen, M.A., Ostrom, E., 2004. A framework to analyze the robustness of social-ecological systems from an institutional perspective. Ecol. Soc. 9, 18.

André, L., Bicho, N., 2016. Perforation techniques and traces of use on the Mesolithic adornments of the Trench Area at Cabeço da Amoreira Shellmidden (Muge, central Portugal). Comptes Rendus Palevol 15, 569e580.

Angelucci, D.E., Soares, A.M., Almeida, L., Brito, R., Leitão, V., 2007. Neolithic occupation and mid-Holocene soil formation at Encosta de Sant'Ana (Lisbon, Portugal): a geoarchaeological approach. J. Archaeol. Sci. 34, 1641e1648.

Araújo, A.C., 2015. A few steps backwards... in search of the origins of the Late Mesolithic. In: Bicho, N., Detry, C., Price, T.D., Cunha, E. (Eds.), Muge 150th: the 150th Anniversary of the Discovery of Mesolithic Shellmiddens, pp. 1e16.

Arias, P., Diniz, M., Araújo, A.C., Armendariz, A., Teira, L., 2015. At the edge of the marshes: new approaches to the Sado valley mesolithic (southern Portugal). In: Bicho, N., Detry, C., Price, T.D., Cunha, E. (Eds.), Muge 150th: The 150th Anniversary of the Discovery of Mesolithic Shellmiddens. Cambridge Scholars Publishing, Muge, pp. 301e320.

Bailey, G., Milner, N., 2002. Coastal hunter-gatherers and social evolution: marginal or central? Before Farming 3/4, 2e15.

Barber, D.C., Dyke, A., Hillaire-Marcel, C., Jennings, A.E., Andrews, J.T., Kerwin, M.W., Bilodeau, G., McNeely, R., Southon, J., Morehead, M.D., Gagnon, J.M., 1999. Forcing of the cold event of 8,200 years ago by catastrophic drainage of Laurentide lakes. Nature 400, 344e348. Bicho, N., 1994. The end of the paleolithic and the mesolithic in Portugal. Curr. Anthropol. 35, $664 \mathrm{e} 674$.

Bicho, N., 1995-1997. A ocupação Epipaleolítica do Abrigo Grande das Bocas, Rio Maior. O Arqueólogo Port. IV, 53e85.

Bicho, N., 2009. Sistemas de povoamento, subsistência e relações sociais dos últimos caçadoresrecolectores do Vale do Tejo. Estud. Arqueol. Oeiras 17, 133e156.

Bicho, N., 2013. Human's best friends e Dogs... and fire. In: Pastoors, A., Auffermann, B. (Eds.), Pleistocene Foragers on the Iberian Peninsula: Their Culture and Environment. Festschrift in Honour of Gerd-christian Weniger for His Sixtieth Birthday, 7. Neanderthal Museum (Wissenschaftliche Schriften des Neanderthal Museums), Mettmann, pp. 217e242.

Bicho, N., Cascalheira, J., Marreiros, J., Gonçalves, C., Pereira, T., Dias, R., 2013. Chronology of the Mesolithic occupation of the Muge valley, central Portugal: the case of Cabeço da Amoreira. Quat. Int. 308e309, 130e139.

Bicho, N., Cascalheira, J., Marreiros, J., Pereira, T., 2011. The 2008-2010 excavations of Cabeço da Amoreira, Muge, Portugal. Mesolith. Misc. 21, 3e13.

Bicho, N., Dias, R., Pereira, T., Cascalheira, J., Marreiros, J., Pereira, V., Gonçalves, C., 2015. O Mesolítico e o Neolítico antigo: o caso dos concheiros de Muge. In: Gonçalves, V., Sousa, A.C. (Eds.), 5. ${ }^{\circ}$ Congresso do Neolítico Peninsular. UNIARQ, Lisbon, pp. 593e600.

Bicho, N., Umbelino, C., Detry, C., Pereira, T., 2010. The emergence of Muge Mesolithic shell middens in Central Portugal and the 8200 cal yr BP cold event. J. Isl. Coast. Archaeol. 5, 86e104.

Butzer, K., 2012. Collapse, environment, and society. PNAS 109 (10), 3632e3639.

Cardoso, J., 2003. A gruta do Correio-Mor (Loures). Estud. Arqueol. Oeiras 11, $229 \mathrm{e} 321$. 
Cardoso, J.L., 2012. A estação do neolítico antigo do Carrascal (Oeiras, Lisboa, Portugal). SAGVNTVM Extra 12, 259e262.

Cardoso, J.L., Carreira, J.R., Ferreira, O.D.V., 1996. Novos elementos para o estudo do Neolítico antigo da região de Lisboa. Estud. Arqueol. Oeiras 6, 9e26.

Cardoso, J.L., Rolão, J.M., 2000. Prospecções e escavações nos concheiros mesolíticos de Muge e de Magos (Salvaterra de Magos): contribuição para a história dos trabalhos arqueológicos efectuados. Estud. Arqueol. Oeiras 8, 83e240.

Carlson, J.M., Doyle, J., 2002. Complexity and robustness. Proc. Natl. Acad. Sci. 99, 2538e2545.

Carvalho, A.F., 2003. A emergência do Neolítico no actual território português: pressupostos teóricos, modelos interpretativos e a evidência empírica. O Arqueólogo Port. 21, 65e150.

Carvalho, A.F., 2007. A neolitização do Portugal meridional: os exemplos do Maciço calcário estremenho e do Algarve ocidental. Unpublished Ph. D. dissertation. Faculdade de Ciências Humanas e Sociais, Universidade do Algarve.

Carvalho, A.F., 2009. O Mesolítico final em Portugal, El mesolítico geométrico en la Península Ibérica. Monogr. Arqueol. 44, 33e68.

Carvalho, A.F., 2010. Chronology and geography of the Mesolithic-Neolithic transition in Portugal. In: Armbruester, T., Hegewisch, M. (Eds.), On Pre- and Earlier History of Iberia and Central Europe. Studies in Honour of Philine Kalb. Verlag Dr. Rudolf Habelt, pp. 45e62.

Carvalho, A.F., Alves-Cardoso, F., Gonçalves, D., Granja, R., Cardoso, J.L., Dean, R.M., Gibaja, J.F., Masucci, M.A., Arroyo-Pardo, E., Fern_andez-Domínguez, E., Petchey, F., Douglas Price, T., Mateus, J.E., Queiroz, P.F., Callapez, P., Pimenta, C., Regala, F.T., 2015. The Bom Santo cave (Lisbon, Portugal): catchment, diet, and patterns of mobility of a Middle neolithic population. Eur. J. Archaeol. 19 (2), 187e214.

Carvalho, A.F., Petchey, F., 2013. Stable isotope evidence of neolithic palaeodiets in the coastal regions of southern Portugal. J. Isl. Coast. Archaeol. 8, 361e383.

Cascalheira, J., Paixão, E., Marreiros, J., Pereira, T., Bicho, N., 2015. Preliminary technotypological analysis of the lithic materials from the Trench area of Cabeço da Amoreira (Muge, Central Portugal). In: Bicho, N., Detry, C., Price, T.D., Cunha, E. (Eds.), Muge 150th: the 150th Anniversary of the Discovery of Mesolithic Shellmiddens, vol. 1. Cambridge Scholars Publishing, Newcastle upon Tyne, pp. 119e133.

Costa, F.A.P.d., 1865. Da existencia do Homem em epochas remotas no valle do Tejo. Primeiro opusculo. Noticia sobre os esqueletos humanos descobertos no Cabeço da Arruda. Imprensa Nacional, Lisboa.

Diniz, M., 2007. O sítio da Valada do Mato (Évora): aspectos da neolitização no Interior/Sul de Portugal (Trabalhos de Arqueologia 48). Instituto Português de Arqueologia, Lisboa.

Erlandson, J.M., 2001. The archaeology of aquatic adaptations: paradigms for a new millennium. J. Archaeol. Res. 9, 287e350.

Fernández, E., Gamba, C., Tirado, M., Carvalho, A.F., Gibaja, J.F., Arroyo-Pardo, E., 2010. The Mesolithic-Neolithic transition in Iberia: insights from ancient DNA. In: Arias, P. (Ed.), MESO2010. Oxbow, Santander. 
Ferreira, T., Umbelino, C., Cunha, E., 2015. The Mesolithic skeletons from Muge: the 21st century xcavations. In: Bicho, N., Detry, C., Price, T.D., Cunha, E. (Eds.), Muge 150th: The 150th Anniversary of the Discovery of Mesolithic Shellmiddens. Cambridge Scholars Publishing, Newcastle upon Tyne, pp. 199e208.

Folke, C., 2006. Resilience: the emergence of a perspective for social-ecological systems analyses. Glob. Environ. Change 16, 253e267. Freeman, J., Anderies, J., 2012. Intensification, tipping points, and social change in a coupled forager-resource system. Hum. Nat. 2 (4), 419e446.

Gonçalves, C., Cascalheira, J., Bicho, N., 2014. Shellmiddens as landmarks: visibility studies on the mesolithic of the Muge valley (Central Portugal). J. Anthropol. Archaeol. 36, 130e139.

Guiry, E.J., Hillier, M., Richards, M.P., 2015. Mesolithic dietary heterogeneity on the European atlantic coastline: stable isotope insights into hunter-gatherer diet and subsistence in the Sado valley, Portugal. Curr. Anthropol. 56, 460e470.

Gunderson, L., Holling, C.S., 2002. Panarchy. Understanding Transformations in Human and Natural Systems. Island Press, Washington.

Gutiérrez-Zugasti, I., Andersen, S.H., Araújo, A.C., Dupont, C., Milner, N., Monge- Soares, A.M., 2011. Shell midden research in Atlantic Europe: state of the art, research problems and perspectives for the future. Quat. Int. 239, 70e85.

Haws, J.A., 2012. Paleolithic socionatural relationships during MIS 3 and 2 in central Portugal. Quat. Int. 264, 61e77.

Holling, C.S., 1973. Resilience and stability of ecological systems. Annu. Rev. Ecol. Syst. 1e23.

Holling, C.S., 2001. Understanding the complexity of economic, ecological, and social systems. Ecosystems 4, 390e405.

Holling, C.S., Gunderson, L.H., Ludwig, D., 2002. In quest of a theory of adaptive change. In: Gunderson, L.H., Holling, C.S. (Eds.), Panarchy: Understanding Transformations in Human and Natural Systems. Island Press, Washington, pp. 3e24.

Jackes, M., Lubell, D., Meiklejohn, C., 1997. Healthy but mortal: human biology and the first farmers of western Europe. Antiquity 71, 639e658.

Janssen, M., Anderies, J., 2007. Robustness trade-offs in social-ecological systems. Int. J. Commons 1 (1), 43e66.

Lubell, D., Jackes, M., 1988. Portuguese Mesolithic-Neolithic subsistence and settlement. Rivista di Antropologia. Roma 66 (Suppl. o), 231e248.

Lubell, D., Jackes, M., Schwarcz, H., Knyf, M., Meiklejohn, C., 1994. The Mesolithic- Neolithic transition in Portugal: isotopic and dental evidence of diet. J. Archaeol. Sci. 21, 201e216.

Marks, A.E., Bieho, N., Zilhão, J., Reid Ferring, C., 1994. Upper Pleistocene prehistory in Portuguese Estremadura: results of preliminary research. J. Field Archaeol. 21, 53e68.

Martins, J.M.M., Carvalho, A.F., Soares, A.M.M., 2008. A calibração das datas de radiocarbono dos esqueletos humanos de Muge. Promontoria, Revista do Departamento de Hist_oria. Arqueol. Património Univ. do Algarve 6, 73e93. 
Meiklejohn, C., Roksandic, M., Jackes, M., Lubell, D., 2009. Radiocarbon dating of Mesolithic human remains in Portugal. Mesolith. Misc. 20 (1), 4e16.

Oosterbeek, L., 1993. Senhora das Lapas: excavation of prehistoric cave burials in central Portugal. Pap. Inst. Archaeol. 4, 49e62.

Pimm, S.L., 1984. The complexity and stability of ecosystems. Nature 307, 321e326.

Peyroteo Stjerna, R., 2016. On Death in the Mesolithic. Or the Mortuary Practices of the Last Hunter-Gatherers of the South-western Iberian Peninsula, $7^{\text {th }}-6^{\text {th }}$ Millennium BCE. Department of Archaeology and Ancient History, Uppsala University, Uppsala.

Price, T.D., 2015. Tracing past human movement: an example from the Muge middens. In: Bicho, N., Detry, C., Price, T.D., Cunha, E. (Eds.), Muge 150th: The 150th Anniversary of the Discovery of Mesolithic Shellmiddens. Cambridge Scholars Publishing, Newcastle upon Tyne, pp. 225e234.

Ramsey, C.B., 1995. Radiocarbon calibration and analysis of stratigraphy; the OxCal program. Radiocarbon 37, 425e 430.

Redman, C.L., 2005. Resilience theory in archaeology. Am. Anthropol. 107, 70e77.

Redman, C.L., Kinzig, A.P., 2003. Resilience of past landscapes: resilience theory, society, and the longue durée. Conserv. Ecol. 7, 14.

Reimer, P., Bard, E., Bayliss, A., Beck, J., Blackwell, P., Bronk Ramsey, C., Buck, C., Cheng, H., Edwards, R., Friedrich, M., 2013. IntCal13 and Marine13 radiocarbon age calibration curves 0-50,000 years cal BP. Radiocarbon 55, 1869e1887.

Rocksandic, M., 2006. Analysis of burials from the new excavations of the sites Cabeço da Amoreira and Cabeço da Arruda (Muge, Portugal). In: Bicho, N., Veríssimo, H. (Eds.), Do Epipaleolítico ao Calcolítico na Península Ibérica. Actas do IV Congresso de Arqueologia Peninsular. Universidade do Algarve, Faro, pp. 43e54.

Rolão, J., 1999. Del Wurm final al Holocénico en el Bajo Valle del Tajo (Complejo Arqueológico Mesolítico de Muge). Unpublished Ph. D. dissertation. Universidad de Salamanca.

Rosen, A., Rivera-Collazo, I., 2012. Climate change, adaptive cycles, and the persistence of foraging economies during the late Pleistocene/Holocene transition in the Levant. PNAS 109 (10), $3640 \mathrm{e} 3645$.

Smit, B., Wandel, J., 2006. Adaptation, adaptive capacity and vulnerability. Glob. Environ. Change 16, 282e292.

Soares, A.M.M., 2005. Variabilidade do 'Upwelling' costeiro durante o Holocénico nas Margens Atlânticas Ocidental e Meridional da Península Ibérica. Unpublished Ph.D. dissertation. Universidade do Algarve, Faro.

Straus, L., 1989. New chronometric dates for the prehistory of Portugal. Arqueologia 20, $73 \mathrm{e} 76$.

Umbelino, C., Gonçalves, C., Figueiredo, O., Pereira, T., Cascalheira, J., Marreiros, J., Évora, M., Cunha, E., Bicho, N., 2015. Life in the Muge Shell Middens: inferences from the New Skeletons Recovered from Cabeço da Amoreira. In: Bicho, N., Detry, C., Price, T.D., Cunha, E. (Eds.), Muge 150th: The 150th Anniversary of the Discovery of Mesolithic Shellmiddens. Cambridge Scholar Publishing, Newcastle upon Tyne, pp. 209e224. 
Umbelino, C., Pérez-Pérez, A., Cunha, E., Hipólito, C., Freitas, M.D.C., Cabral, J.P., 2007. Outros sabores do passado: um novo olhar sobre as comunidades humanas mesolíticas de Muge e do Sado através de análises químicas dos ossos. Promontoria 5, 45e90.

Umbelino, C.I.S., 2006. Outros sabores do passado: as análises de oligoelementos e de isótopos estáveis na reconstituição da dieta das comunidades humanas do Mesolítico Final e do Neolítico Final-Calcolítico do território português. Unpublished Ph.D. dissertation. Universidade de Coimbra, Coimbra.

van der Schriek, T., Passmore, D.G., Franco Mugica, F., Stevenson, A.C., Boomer, I., Rolão, J., 2008. Holocene palaeoecology and floodplain evolution of the Muge tributary, lower Tagus basin, Portugal. Quat. Int. 189, 135e151.

von Grafenstein, U., Erlenkeuser, H., Müller, J., Jouzel, J., Johnsen, S.J., 1998. The cold event 8200 years ago documented in oxygen isotope records of precipitation in Europe and Greenland. Clim. Dyn. 14, $73 \mathrm{e} 81$.

Walker, B.H., Holling, C.S., Carpenter, S.R., Kinzig, A.P., 2004. Resilience, adaptability and transformability in socialeecological systems. Ecol. Soc. 9, 5.

Zilhão, J., 1993. The spread of agro-pastoral economies across Mediterranean Europe: a view from the far west. J. Mediterr. Archaeol. 6, 5e63.

Zilhão, J., 2000. From the Mesolithic to the Neolithic in the Iberian Peninsula, Europe's First Farmers. Cambridge University Press, Cambridge, pp. 144e182.

Zilhão, J., 2001. Radiocarbon evidence for maritime pioneer colonization at the origins of farming in west Mediterranean Europe. Proc. Natl. Acad. Sci. 98, 14180e14185.

Zvelebil, M., 2003. People behind the lithics: on social structure and ideology of Mesolithic hunter-gatherers in Europe. In: Bevan, L.A.M.J. (Ed.), Peopling the Mesolithic in a Northern Environment. BAR, Oxford, pp. 1e26. 